archives-ouvertes

\title{
Dissolved organic carbon in coral-reef lagoons, by high temperature catalytic oxidation and UV spectrometry
}

Jean Pages, Jean-Pascal Torreton, Richard Sempere

\section{To cite this version:}

Jean Pages, Jean-Pascal Torreton, Richard Sempere. Dissolved organic carbon in coral-reef lagoons, by high temperature catalytic oxidation and UV spectrometry. Comptes Rendus Géoscience, Elsevier Masson, 1997. <hal-02062734>

\section{HAL Id: hal-02062734 \\ https://hal-amu.archives-ouvertes.fr/hal-02062734}

Submitted on 9 Mar 2019

HAL is a multi-disciplinary open access archive for the deposit and dissemination of scientific research documents, whether they are published or not. The documents may come from teaching and research institutions in France or abroad, or from public or private research centers.
L'archive ouverte pluridisciplinaire HAL, est destinée au dépôt et à la diffusion de documents scientifiques de niveau recherche, publiés ou non, émanant des établissements d'enseignement et de recherche français ou étrangers, des laboratoires publics ou privés. 


\title{
Dissolved organic carbon in coral-reef lagoons, by high temperature catalytic oxidation and UV spectrometry
}

\author{
Jean Pagès, Jean-Pascal Torréton and Richard Sempéré
}

\author{
J.P. and J.-P. T.: Centre ORSTOM de \\ Tahiti, BP 529, Papeete, Tahiti, \\ Polynèsie française. \\ E-mail: pages@tahiti.rio.net \\ R. S.: Centre océanologique de \\ Marseille, case 901, F-13288 Marseille \\ cedex 9 , France.
}

Abstract Two surveys were carried out on ten atolls in the Tuamotu archipelago (French Polynesia, Pacific Ocean). In vitro UV (250 $400 \mathrm{~nm}$ ) spectra of water samples gave absorption at $254 \mathrm{~nm}, \mathrm{~A}_{254}$, and spectrum slope, $S^{*}$ (computed from $\ln A_{2}$ versus $\lambda$ ). These two descriptors are negatively correlated, and data points are arrayed along a hyperbola spanned between an oceanic pole (high $S^{*}$, low $A_{254}$ ) and a confined pole (low 5*, high $A_{254}$ ).

Dissolved organic carbon (DOC) concentrations, [C], as assessed by HTCO, exhibit a narrow range (0.7-1.0 mg C.L $L^{-1}$ for most lagoons) contrasting with the wide diversity of optical characteristics. [C] and $A_{234}$ are positively correlated, with a significant intercept $(0.5 \mathrm{mg} \mathrm{C.L-1})$ representing non-chromopharic DOC. Carbon-specific absorption, $\varepsilon_{254}$, increases (from 0.4 to $1.3 \mathrm{~m}^{2} \cdot \mathrm{g}^{-1}$ ) with increasing $[C]$, mainly according to the literature) owing to increased average molecular weight (MW) of the chromophoric DOC fraction, which also lowers $5^{*}$.

Our optical data thus illustrate a gradient of confinement (or residence time) that corresponds to a continuum in DOC nature, especially in MW and hence in bioavailability. Optical methods are confirmed as quick and effective means of assessing DOM distribution.

Keywords: Coral reef lagoons, Dissolved organic carbon, Specific UV absorption, Tuamotu, France.

Résumé Carbone organique dissous dans des lagons d'atoll, par combustion catalytique à haute température et par spectrophotométrie

Deux campagnes ont prospecté dix lagons d'atoll des Tuamotu (Polynésie française, océan Pacifique). Sur des échantillons d'eau, le spectre UV (250-400 nm) in vitro est décrit par l'absorption à $254 \mathrm{~nm}, A_{254}$, et la pente, $S^{*}$ (régression de $\ln A_{\lambda} v s \lambda$ ). Ces deux descripteurs sont négativement corrélés. Les points $s^{\prime}$ organisent le long d'une hyperbole entre un pôle océanique (fort $S^{*}$, faible $A_{254}$ ) et un pôle confiné (faible $S^{*}$, fort $A_{254}$ ).

Le carbone organique dissous (COD) présente des concentrations ([C], déterminées par HTCO) peu variables $\left(0,7-1,0 \mathrm{mg} C . L^{-1}\right)$, contrastant avec la large diversité des propriétés optiques. [C] et $A_{254}$ ont une corrélation positive, avec une ordonnée à l'origine significative $\left(0,5 \mathrm{mg} \mathrm{C.L} \mathrm{L}^{-1}\right)$ correspondant à une fraction " non chromophorique " du COD. L'absorption spécifique ramenée au carbone, $\varepsilon_{254}$, croît (de 0,4 à $1,3 \mathrm{~m}^{2} \cdot \mathrm{g}^{-1}$ ) pour des $[\mathrm{C}]$ croissantes, surtout (d'après la littérature) en relation avec une augmentation du poids moléculaire moyen, qui abaisse les valeurs de $S^{*}$.

Nos mesures optiques décrivent ainsi un gradient de confinement (ou de temps de séjour) qui correspond à un continuum dans la nature du COD, dont son poids moléculaire et donc sa susceptibilite à une action biologique. Cette méthode rapide confirme son efficacité pour la description de la distribution de la MOD.

Mots clés : Lagons d'atoll, Carbone organique dissous, Absorption spécifique UV, Tuamotu, France.

Note

présentée par Georges Pédro.

remise le 13 novembre 1996. acceptée après révision le 24 février 1997. 
Version
française
abrégée ALGRÉ l'ímportance quantilative de lda matière organique dissoute (MOD) marine dans le cycle global du carscule unc faible fraction de cette MOD pcut être identifiée chimiquement. Or, la na ture de la MOD conditionne, entre autres, son utilisation par les bactérics hétérotrophes. Si l'identification fine est cxclue, la reconnaissance de grandes catégorics (par exemple sur la base du poids moléculaire) semble possible par des méthodes non chimiques. Nous avons employé la spectrophotométrie dans l'ultraviolet (entre 250 el $400 \mathrm{~nm}$ ), qui permet un classement semi-quantitatif de types de MOD. Parallc̀lement, un dosage classique du carbone organique dissous (COD; Shimadzu TOC-5000) fournit une comparaison avec les données optiques, en même temps que des valcurs absolues. Les observations, réalisées dans le cadre du programme TypAtoll, ont ćté effectuées sur dix atolls des Tuamou, au cours de deux campagnes.

Les spectres d'absorption sont décrits par leur pente, $S^{*}$, et l'absorption à $254 \mathrm{~nm}, A_{25,4}$. Ces deux descripteurs présentent unc corrélation négative (fig. $1 ; \quad r^{1}=0,60$, $\mathrm{n}=327$ points). Chaque lagon fournit un nuage de points bien groupés, nettement séparé de celui des autres lagons. Nous déterminons que la distribution des échantillons le long de la courbe de régression correspond à un gradient de confinement entue deux cxtrêmes : d'une part, des eaux "océaniques ", oliyourophes, à fort $S^{*}$ et faible $A_{25,}$ d'autre part des eaux " confinées ", ou mésotrophes, à fort $A_{2,51}$ ct faible $S^{*}$.

Les concentrations en COD, [C], sont asscz homogènes $\left(0,7\right.$ à $1,0 \mathrm{mg}\left(. \mathrm{L}^{-1}\right)$ dans la plupart des lagons. Rekareka et Taiaro, lagons confinés, font exception ([C] de 1,1 et $1,8 \mathrm{mg}$ C.. $\mathrm{L}^{-1}$ respectivement). Le (COD est bien corrélé avec $A_{254}\left(r^{2}=0,8\right)$, malgré les échantillons océaniques, à léger excès de COD par rapport à leur $A_{254}$ (fig. 2). Cette régression présente une vrdonnée à l'origine d'environ $0,5 \mathrm{mg} \mathrm{C.L} \mathrm{L}^{-1}$ qui correspond à une fraction optiquement inactive. L'absorption spécifique (ramenée au COD), $\varepsilon_{25.4}$ varie entre $0,4 \mathrm{et}$ $1,4 \mathrm{~m}^{2} \cdot \mathrm{gC}^{-1}$. Elle présente une corrélation négative avec $S^{*}\left(1 / \varepsilon_{2,-1}\right.$ vs $\left.1 / S^{*} ; r^{2}=0,62\right)$.

Nous vérifions que la concentration en COD prédite à partir de $\mathrm{A}_{2: 1}\left[\mathrm{C}_{\mathrm{A}}\right]$, diffère peu $\left( \pm 0,1 \mathrm{mg} \mathrm{C.L} \mathrm{L}^{-1}\right.$ en moyenne) de la concentration déterminée par HTCO, $\left[\mathrm{C}_{\mathrm{m}}\right]$ (fig. 3).

Lne part de la variation de $\varepsilon_{25.1}$ (augmentation pour des $[\mathrm{C}]$, et des $\mathrm{A}_{2534}$, croissants) peut êre due au seul artefact "mathématique " de la présence du COD optiquement inactif, mais la proportion de COD « chromophorique " peut aussi varier. Enfin, selon la littérature, l'évolution de $\varepsilon_{25: 1}$ et de $S^{*}$, reflète aussi la variation du poids moléculaire moyen de cette fraction optiquement active. Les caractéristiques optiques du COD varient beaucoup plus que la valeur globale fournie par le dosage HTCO "classique ", en relation avec la nature de la MOD, et donc en fonction de son histoire. Sa susceptibilité à une attaque biologique en dépend.

Les méthodes optiques sont rapides, et nous confirmons leur efficacité pour l'étude qualitative et semi-quantitative de la distribution de la MOD naturelle.

\section{INTRODUCTION}

It is well accepted that dissolved organic matter (DOM) represents the main organic compartment in the global aquatic carbon stock. Despite this importance, several authors have explicitly underlined that only a small part $(5-30 \%)$ of marine DOM can be chemically characterized (Collins and Williams, 1977; Chen and Bada, 1992; Benner et al., 1992; Lee and Henrichs, 1993; Amon and Benner, 1996). This has a direct consequence on the perspectives of assessing DOM's bioavailability, which is at least as important as knowing total DOC concentration (see example in Benner ot al., 1995). Describing "bulk characteristics" of marine DOM will thus remain a plausible aim, while it would be 
useful to recognize some broad categories (Hobbie, 1992), for instance through nonchemical methods (Coble $t$ t ul., 1990).

Among these, optical characteristics have been widely used, perhaps more often in continental waters (partial review in Moore, 1987) than in open-sea waters. We applied spectrophotometry to characterize the waters of several coral-reef lagoons, with the initial aim of a typological, semi-quantitative classification (Pagès et al., 1997). We could thus describe the distribution of qualitative characters of DOM (or at least of its "chromophoric" part) among different lagoons. Here, we compare these results with those of the classical HTCO (high temperature catalytic oxidation) assessment of DOC concentration, to determine whether i) there is a relationship between optical properties and DOC concentration, and ii) we can predict DOC from optics.

\section{MATERIAL AND METHODS}

Our observations were part of several programs studying the general biological produc- tion of atoll lagoons, and more specifically the processes in the water column. The main series of samples was taken during surveys (the "Typatoll" cruises) carried out in November 1995 ("Typatoll 3") and March 1996 ("Typatoll 4"), during which we studied a total of ten atolls in the Tuamou archipelago $\left(15-18^{\circ} \mathrm{S}\right.$, $\left.141-146^{\circ} \mathrm{W}\right)$. Open-sea samples were also collected. Some characteristics of the lagoons studied here are given in table $\mathbf{I}$.

Sampling was performed within a few hours on each atoll, at 5-8 stations (see details in Pagès el al., 1997).

Spectrophotometry was performed on board during the surveys. We used a Milton Roy "Spectronic 1201" fitted with a $100 \mathrm{~mm}$ quartz cell. We measured absorption $\left(A_{\lambda}\right)$ at 12 discrete wavelengths between 250 and $400 \mathrm{~nm}$ against blanks of distilled de-ionized water. Reproducibility of absorption values is good. Mean coefficient of variation on $71 \mathrm{du}$ plicates (cither successive sub-samples or duplicate samples) is 0.019 (i.e. less than $2 \%$ ).

For DOC assessment, samples $(11-\mathrm{mL})$ were not filtered (De Baar el al. 1993), but preserved with $\mathrm{HgCl}_{2}\left(200 \mu \mathrm{L}\right.$ of a $0.5 \mathrm{~g} . \mathrm{L}^{-1}$

Table I Some averaged characteristics of the lagoons studied (lagoons in alphabetical order).

Données moyennes des lagons étudiés (par ordre alphabétique)

\begin{tabular}{|c|c|c|c|c|c|c|c|c|c|c|c|c|}
\hline \multirow{2}{*}{ Lagoon } & \multirow{2}{*}{ Area } & \multirow{2}{*}{2} & \multicolumn{2}{|c|}{$A_{254}$} & \multicolumn{2}{|c|}{$\mathbf{S}^{*}$} & \multicolumn{2}{|c|}{ DOC } & \multicolumn{2}{|c|}{$\varepsilon_{254}$} & \multicolumn{2}{|c|}{ POC } \\
\hline & & & $T 3$ & $T 4$ & T3 & T4 & $T 3$ & $T 4$ & T3 & T4 & $T 3$ & T4 \\
\hline Haraiki & 10.4 & 8.3 & 0.80 & 0.93 & 0.018 & 0.015 & 0.88 & 0.78 & 0.91 & 1.19 & 0.11 & 0.18 \\
\hline Hikueru & 82.5 & 18 & 0.67 & 0.74 & 0.023 & 0.025 & 1.05 & 0.96 & 0.65 & 0.77 & 0.05 & 0.11 \\
\hline Hiti & 15.3 & 8 & 0.79 & 0.75 & 0.020 & 0.019 & 0.96 & 0.95 & 0.83 & 0.79 & 0.11 & 0.12 \\
\hline Kauehi & 315 & 32 & 0.47 & 0.55 & 0.022 & 0.024 & 0.91 & 0.85 & 0.52 & 0.65 & 0.05 & 0.09 \\
\hline Marokau & 217 & 20 & 0.61 & 0.65 & 0.024 & 0.021 & 0.76 & 0.88 & 0.80 & 0.74 & 0.09 & 0.11 \\
\hline Nihiru & 79 & 18 & 0.74 & 0.71 & 0.021 & 0.018 & 0.075 & 0.74 & 0.99 & 0.97 & 0.06 & 0.11 \\
\hline Rekareka & 0.74 & 1.0 & 1.43 & 1.28 & 0.016 & 0.015 & 1.20 & 1.03 & 1.18 & 1.25 & 0.22 & 0.23 \\
\hline Taıro & 11.8 & 12 & 2.58 & 2.13 & 0.022 & 0.025 & 1.91 & 1.72 & 1.36 & 1.24 & 0.18 & 0.20 \\
\hline Tekokota & 5.1 & 3 & 0.45 & 0.43 & 0.022 & 0.019 & 0.75 & 0.74 & 0.61 & 0.58 & 0.05 & 0.09 \\
\hline Tepoto Sud & 1.6 & 5 & 0.68 & 0.47 & 0.018 & 0.023 & 0.90 & 0.76 & 0.77 & 0.62 & 0.13 & 0.12 \\
\hline Ocean & - & - & 0.40 & 0.37 & 0.036 & 0.043 & 0.98 & 1.03 & 0.42 & 0.36 & 0.05 & 0.05 \\
\hline
\end{tabular}

Each figure is based on six separate stations. For each characteristic, twin columns give the results from Typatoll 3 (T3) and Typatoll 4 (T4) surveys. Lagoon area in $\mathrm{km}^{2}$; averaged depth (Z) in $\mathrm{m}$; absorption $\mathrm{A}_{254}$ in $\mathrm{m}^{-1}$; spectrum slope $\mathrm{S}^{*}$ in $\mathrm{nm}^{-1}$; carbon-specific absorption $\varepsilon_{254}$ in $\mathrm{m}^{2}$. (g C) ${ }^{-1}$; DOC and POC in $\mathrm{mg} C \cdot \mathrm{L}^{\prime}{ }^{\prime}$

Chaque valeur est fondée sur six stations distinctes. Pour chaque paramètre, deux colonnes donnent les résultats des deux campagnes, Typatoll 3 (T3) et Typatoll 4 (T4). 
Fig. 1 spectrum slope, $S^{*}$, versus absorption at $254 \mathrm{~nm}, \mathrm{~A}_{254}$. Symbols represent oceanic waters $(\boldsymbol{D})$, Rekareka (A) Taiaro (+), and other atoll lagoons (C). Solid curve represents the functional linear regression of $1 / 5^{*}$ versus $1 / A_{254}$ (see table II)

Pente des spectres d'absorption $S^{*}$ par rapport à l'absorption à $254 \mathrm{~nm}, A_{254}$. Symboles : eaux océaniques (n); eaux des lagons, Rekareka (A), Taiaro (+), autres (O). La courbe continue est celle de la régression linéaire fonctionnelle de $1 / 5$ en fonction de $1 / A_{254}$ (voir tableau II). solution) and $\mathrm{HCl}(50 \mu \mathrm{L}$ of a $6 \mathrm{~N}$ solution), and kept at $5{ }^{\circ} \mathrm{C}$ on board. Measurements were made (at least in duplicate) with standard HTCO techniques on a Shimadzu TOC 5000 . Mean standard error on duplicates was $0.046 \mathrm{mg} \mathrm{C.L} \mathrm{L}^{-1}$, i.e. $4.3 \%$. These TOC figures were then corrected for particulate organic carbon (POC), which we determined with a Leco $\mathrm{CHN}$ analyzer.

\section{RESULTS}

\section{Spectral parameters and qualitative aspects}

Most of this section has been expounded elsewhere (Pagès et al., 1997), but must be briefly recalled for comprehension of the following.

Absorption spectra show the classical linear relation between $\ln A$, and $\lambda$ (Bricaud $t$ al., 1981). Spectrum slope ( $\mathrm{S}^{*}$ ) values range between 0.009 and $0.030 \mathrm{~nm}^{-1}$ in atolls, while oceanic samples exhibit higher values, up to $0.040 \mathrm{~nm}^{-1}$ (table I). Absorption at $254 \mathrm{~nm}$

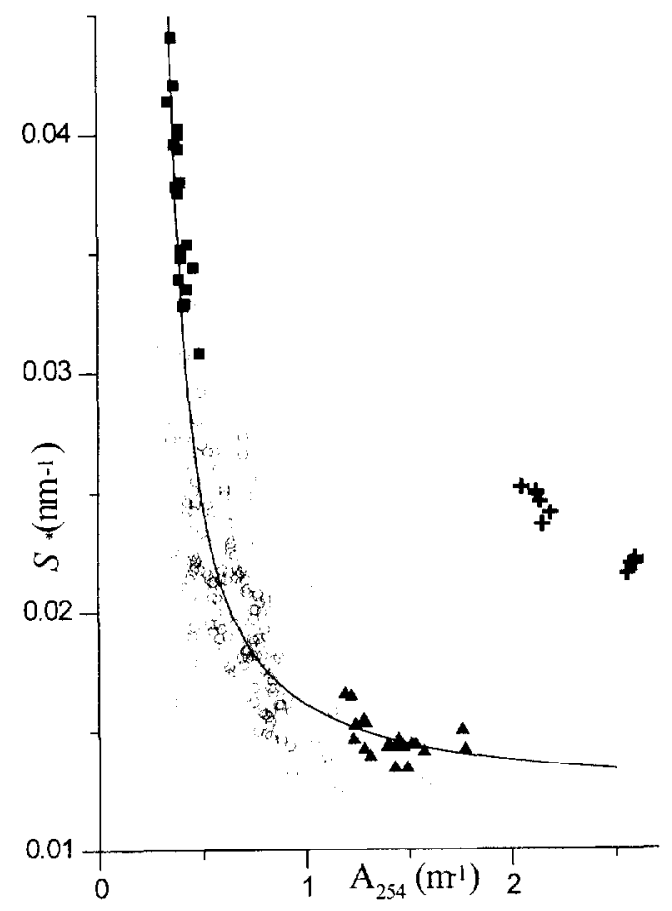

$\left(\mathrm{A}_{254}\right)$ mostly ranges between 0.5 and $0.8 \mathrm{~m}^{-1}$, with lower values $\left(0.4 \mathrm{~m}^{-1}\right)$ in oceanic samples, and higher values (up to about $2 \mathrm{~m}^{-1}$ ) in some confined lagoons (Rekareka and Taiaro).

A plot of $A_{254}$ against $S^{*}$ for all lagoon and seawater samples (fig. 1) shows an inverse correlation between these two descriptors. The waters from Taiaro, a closed lagoon with abundant terrestrial vegetation, are conspicuous oulliers. Their abnormally high $\mathrm{S}^{*}$ values stem from the presence of lignin degradation products and humic acids (ms in prep.). Excluding this lagoon, the best fit $\left(r^{2}=0.60\right)$ is given by the regression of $\left(1 / S^{*}\right)$ against $\left(1 / A_{254}\right)$ (see table II).

Data points are not randonly distributed along this hyperbolic regression curve. Spatially detailed observations in Tikehau lagoon (see details in Pagès et al., 1997) show that dala points are arranged between an "oceanic" pole, with high $S^{*}$ values $\left(\sim 0.04 \mathrm{~nm}^{-1}\right)$ and low $\mathrm{A}_{254}\left(0.4 \mathrm{~m}^{-1}\right)$, and a "eutrophic" pole, with low $S^{*}\left(<0.01 \mathrm{~nm}^{-1}\right)$ and high $A_{2,24}$ $\left(>2 \mathrm{II}^{-1}\right)$. By mixing different water types, we could see that the observed hyperbola corresponds to mixtures, in varying proportions, between two main types of water reflecting the above description of the two poles. We are thus dealing with a continuum of waters between which there is no basic difference, but only a continuous variation of proportions.

\section{Quantitative aspects: DOC and carbon- specific absorbance}

\section{(a) DOC concentrations}

For most lagoon samples, DOC concentrations $[\mathrm{C}]$ exhibit a narrow range, from 0.7 to $1.0 \mathrm{mg} \mathrm{C.L^{-1 }}$ (table I), against $[\mathrm{C}]$ values of $\sim 1.0 \mathrm{mg} \mathrm{C.} \mathrm{L}^{-1}$ in oceanic samples. Relatively high DOC concentrations are only found in Rekareka and Taiaro (averaging 1.11 and $\left.1.82 \mathrm{mg} \mathrm{C.L} \mathrm{L}^{-1}\right)$. Intra-lagoon variability is very low in most cases. Coefficient of variation (CV) for a given lagoon on a given survey generally amounts to $\sim 5 \%$, and this includes the (low) analytical variability. If we consider only "normal" lagoons and oceanic samples, 
Table II Functional correlations (Ricker, 1973) between variables.

Corrélations fonctionnelles (Ricker, 1973) entre variables.

\begin{tabular}{cccccccc}
\hline $\mathbf{X}$ & $\mathbf{Y}$ & Data & Slope & Intercept & $\mathbf{P}$ & $\mathbf{n}$ & $\mathbf{P}$ \\
\hline $1 / A_{254}$ & $1 / S^{*}$ & all data & -16.6 & 75.3 & 0.60 & 327 & $<0.001$ \\
$A_{254}$ & {$[C]$} & all data & 0.553 & 0.508 & 0.76 & 142 & $<0.001$ \\
$A_{254}$ & {$[C]$} & without oceanic samples & 0.580 & 0.465 & 0.83 & 130 & $<0.001$ \\
$1 / S^{*}$ & $1 / \varepsilon_{254}$ & without oceanic samples & -0.034 & 3.069 & 0.62 & 130 & $<0.001$ \\
{$\left[C_{A}\right]$} & {$\left[C_{r}\right]^{2}$} & lagoon averages, without oceanic samples & 0.898 & 0.075 & 0.86 & 20 & $<0.001$ \\
\hline
\end{tabular}

[C]: Dissolved organic carbon concentration, in $\mathrm{mg} C . L^{-1} ; C_{\mathrm{m}} \mathrm{l}$ : measured DOC concentration $\left[C_{A}\right]$ : DOC concentration; computed from $A 254$ and the $A_{2 b 4}$-versus- $[C]$ regression (without oceanic samples).

they exhibit a 1.5 -fold amplitude for $[\mathrm{C}]$, against a two-fold one for $\mathrm{A}_{254}$ (see table $\mathbf{I}$ ).

Absorption, $A_{254}$ (in $\mathrm{m}^{-1}$ ), is correlated with DOC concentration (fig. 2 and table II). The overall regression $\left(r^{2}=0.76\right)$ is slightly improved $\left(r^{2}=0.84\right)$ when occanic samples exhibiting "too much" DOC are excluded. We can note that this correlation is acceptable only after including the "high DOC" lagoons (Taiaro and Rekareka); with "normal" lagoons only, the correlation is statistically significant $(\mathrm{r}=0.521, \mathrm{n}=107, \mathrm{P}>0.001)$ but the regression is worthless in terms of predicting [C] from $A_{254}$. The other salient point is the intercept, amounting to about $0.5 \mathrm{mg} \mathrm{C.L^{-1 }}$ of DOC without optical activity.

Inspection of the results indicates that $A_{254}$ allows a better discrimination between lagoons than does [C]. To quantity the discriminative potential of $A_{254}$ and $[C]$, we tested the null hypothesis of a homogeneous population comprising all stations in all lagoons and the ocean during the two surveys (22 sets of six data each), using the Kruskal-Wallis one-way analysis by ranks (two-by-two comparison on rank sums of adjacent sets; 21 comparisons). Significance of the differences between lagoons was also tested using the Mann-Whitney test (two-by-two comparison on all data; 213 (i.e. $21+20+19+\ldots$ ) comparisons). Results of the two tests confirm that optics are more able to discriminate between lagoons than chemical (HTCO) DOC measurements.

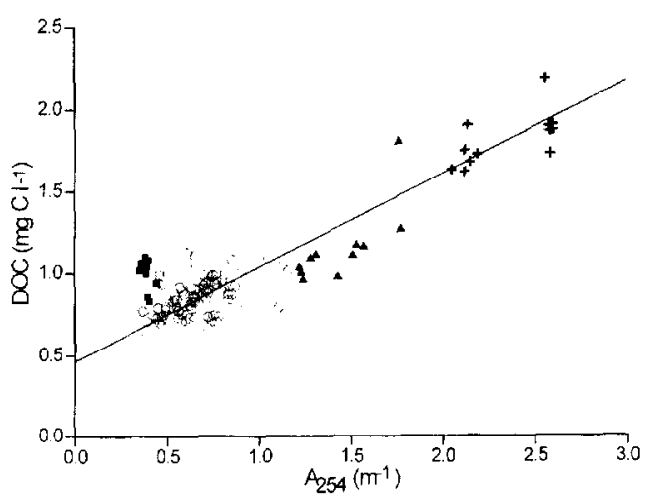

Fig. 2 DOC concentration versus $A_{254}$ Same symbols as in figure 1 . Oceanic samples are not included in the $f_{i}$ tted line.

COD en fonction de $A_{254}$. Les symboles sont les mêmes que ceux de la figure 1. Les échantillons oceaniques sont exclus de la ligne droite.

\section{(b) Specific absorption}

We computed carbon-specific absorption as $\varepsilon_{2.54}=A_{2.54} /[C]$, with $A$ in $m^{-1}$ and $[C]$ in mg C. $\mathrm{L}^{-1}$. Values of $\varepsilon_{25.5}$ (see table $\mathrm{I}$ ) range between 0.5 and $1.0 \mathrm{~m}^{2} \cdot \mathrm{g}^{-1}$ in "normal" lagoons, but are higher for Rekareka and Taiaro lagoons $\left(1.2-1.3 \mathrm{~m}^{2} \cdot \mathrm{g}^{-1}\right)$, while oceanic samples exhibit low $\varepsilon_{251}$ values $\left(\sim 0.4 \mathrm{~m}^{2} \cdot \mathrm{g}^{-1}\right)$.

Comparison between $\varepsilon_{254}$ and spectrum slope $S^{*}$ shows a general inverse trend (high $\varepsilon_{254}$ values for low $\left.S^{*}\right)$, with Taiaro samples as prominent outliers (figure not shown). Excluding Taiaro, the best fit is given by a hyperbolic $\left(1 / \varepsilon_{254}\right.$ versus $\left.1 / S^{*}\right)$ equation with significant correlation $\left(r^{\prime}=0.62, \quad P<0.001\right.$ for $\mathrm{n}=130$ ). Data points appear too widely scattered (figure not shown) for a satisfactory prediction of $\varepsilon_{25,4}$ from $S^{*}$. 


\section{(c) Prediction of DOC concentration}

The various correlations seen above should allow determination of DOC concentration, $[\mathrm{C}]$, from optical properties, in particular from the regression between $A_{254}$ and DOC concentration. We obtain a set of computed values, $\left[C_{A}\right]$, which we compare with actual (measured) values [Cm] (see fig. 3).

In the narrow range of "normal" lagoons $(n=96)$, mean values $( \pm$ s.d.) agree very well: $0.852( \pm 0.096)$ for $[\mathrm{Cm}]$, against 0.827 $( \pm 0.083)$ for $\left[C_{A}\right]$. For oceanic samples, $\left[C_{A}\right]$ values are underestimated $\left(0.68 \mathrm{mg} \mathrm{C.L}{ }^{-1}\right.$ instead of 1.00), in accordance with the divergence between $[\mathrm{Cm}]$ and $\mathrm{A}_{25,4}$ (section (a)). Considering now the whole range, with the two "eutrophic" lagoons (Rekareka and Taiaro), we obtain a high correlation $\left(\mathrm{r}^{2}=0.857\right)$ between $[\mathrm{Cm}]$ and $\left[\mathrm{C}_{\hat{A}}\right]$ (see fig. 3 and table II).

\section{DISCUSSION}

The relations we found between optical properties and DOC concentration, $[C]$, have two aspects: i) quantified prediction of [C] and ii) semi-quantified evaluation of the nature of the DOC.

Optics, and especially absorption at a given wavelength, have been widely used as a proxy estimator (or a "surrogate parameter" (Summers et al., 1987)) of DOM concentration, in the laboratory or in the field. Even if caution is necessary in some particular environments, such as hard-water lakes (Stewart

Fig. 3 DOC calcuiated from $A_{254}$ compared to measured values. Same symbo.s as in figure 1

COD calculé à partir de $A_{254}$ par rapport aux valeurs determinées expérimentalement. Symboles: voir la figure 1. and Wetzel, 1981), optical measurements provide an interesting method for DOC assessment, once duly calibrated. In our case, agreement between measured $[\mathrm{Cm}]$ and computed $\left[\mathrm{C}_{\lambda}\right]$ is reasonable $\left(\mathrm{r}^{2} \sim 0.86\right)$ across the whole range studied here (including Rekareka and Taiaro).

Excluding Rekareka and Taiaro, the "normal" lagoons show a small relative variation in cotal DOC concentration (range 0.74-1.05 mg C.. $\left.\mathrm{L}^{-1}\right)$. This contrasts with the much wider variation in absorption $\left(\mathrm{A}_{2.54}\right.$ ranging between 0.43 and $0.93 \mathrm{~m}^{-1}$ ). We have seen that $A_{254}$ discriminates better between lagoons than does bulk DOC concentration. The sensitivity of optical characteristics (both $\varepsilon_{2.54}$ and $S^{*}$ ) to minute variations in DOM nature and/or concentration has been shown in a previous paper (Pagès et al., 1997).

The DOC concentrations we found are quite normal for oligo- to mesotrophic waters (Martin and Fitzwater, 1992; Guo et al., 1994; Carlson and Ducklow, 1995). In these "normal" lagoons, then, the purely quantitative aspect of optical measurements is useful only as a preliminary estimation of bulk DOC concentration, especially when considering the cost/benefit ratio (see the analogous conclusion reached by Moore, 1987).

The semi-quantitative evaluation of DOC nature has higher potentials. Our argumentation is based on (i) the $\mathrm{A}_{2: 3}$-versus-S* distribution, and (ii) the correlation between $[\mathrm{C}]$ and $A_{254}$. This latter shows the existence of a "residual" colourless DOC fraction amounting to about $0.5 \mathrm{mg} \mathrm{C.L} \mathrm{L}^{-1}$. Such an optically inactive fraction (appearing as the intercept in the $[\mathrm{C}]$-versus-A $\mathrm{A}_{2,4}$ regression) has been found in other environments, at concentrations ranging between 0.4 and $0.9 \mathrm{mg} \mathrm{C.L} \mathrm{L}^{-1}$ in oceanic samples (Amador et al., 1990; Vodacek et al., 1995) and between 2 and $6 \mathrm{mg} \mathrm{C.L} \mathrm{L}^{-1}$ in coastal or continental waters (De Haan and De Boer, 1987).

The relative increase in the ratio between active and inactive $\mathrm{C}$ at increasing $[\mathrm{C}]$ leads to the mathematical artifact of increasing $\varepsilon_{2-5.1}$. even if the "true" specific absorption $\left(\varepsilon^{*}\right)$ were constant, which is not necessarily true (see below). 
Our $\varepsilon_{z:, 4}$ varies between 0.6 and $1.4 \mathrm{~m}^{2} \cdot \mathrm{g}^{-1}$ in the lagoons studied. We found only one comparable value $\left(0.29 \mathrm{~m}^{2} \cdot \mathrm{g}^{-1}\right)$, obtained on marine fulvics (Carder et al., 1989). Most other published values range between 3 and $11 \mathrm{~m}^{2} \cdot \mathrm{g}^{-1}$, but were obtained with isolated fractions (humics or fulvics) of various aquatic origins (Summers el al., 1987; De Haan et al., 1988; Blough et al., 1993).

Among the identified factors of variation of $\varepsilon$ (at any wavelength) are ionic strength (Summers el al., 1987; De Haan el al., 1987) and pH (De Haan el al., 1983), which are irrelevant for our measurements on natural seawater. We deal here with marine DOM, which is an undetermined mixture of molecules (Amon and Benner, 1996). The chief factor controlling $\varepsilon$ in natural samples will be average molecular weight, MW, or "molecular size". Several studies show, more or less explicitly, a positive correlation betwcen $\varepsilon$ and $\log$ MW, and a negative correlation between spectrum slope $S^{*}$ (or the equivalent ratio E2/E3 (De Haan et al., 1988) and MW (Stewart and Wetzel, 1980; Dc Haan el al., 1983; Summers el al., 1987; Senesi et al., 1989).

The "confincd" pole, with high $\Lambda_{254}$ (and high $[\mathrm{C}]$ ) corresponds to gradually increased average MW (as cvidenced by the low $\mathrm{S}^{*}$ values), as found in other environments (Tranvik, 1990; Guo et al., 1994). The increase in $\varepsilon_{2.5}$ in this chromophoric portion may be also duc to a parallel (and slight) increase in the proportion of high- $\varepsilon^{*}$ molecules (Blough et al., 1993), such as lignin derivatives, or UVprotecting compounds (Shick el al., 1992).
The continuity that we observe betwcen lagoons suggests a continuum of MW, such as is described by several authors (Moran el al., 1991; Guo et al., 1994; Amon and Benner, 1996). This array of MWs can result in part from bacterial heterotrophic activity, which leads to decreased $S^{*}$ (Blough et al., 1993). Bacterial uptake induces very small variations in bulk properties (Brophy and Carlson, 1989), but may alter the more sensitive optical properties of DOM.

\section{CONCLUSIONS}

Optical characteristics allow the prediction of DOC concentration with an accuracy of about $\pm 0.1 \mathrm{mg} \mathrm{C.L} \mathrm{L}^{-1}$ (avcragc absolute difference between $[\mathrm{Cm}]$ and $\left[\mathrm{C}_{\mathrm{B}}\right]$ ). The main potential of optics lics though in the ability to detect minute variations, or alterations, in the naturc of DOC, or at lcast of its "chromophoric" portion.

We have noted that our data points (our lagoon samples) are arrayed, in the $A_{254^{-}}$ versus-S* plane, betwecn two polcs. A distance along the regression curve (measured on the graph from the data points for open-sca samples) would then also correspond to a factual distance (in space and/or in time) between the open sea and a water body. Optical characteristics would then estimate confinement. We could verify their good correlation with chlorophyll concentration Pagès et al., 1997), which has been shown to be related to water residence time (Furnas et al., 1990; Delesalle and Sournia, 1992).

Acknowledgements: The "TypAtoll" program was funded by ORSTOM, PNRCO and French Polynesia's Délégation à la Recherche. We thank the crews of French Navy patrol-boat "La Railleuse" and RN "Alis" for their cooperation. Measurements of POC were done by 5 . Bonnet and by N. Garcia. Discussions with J.T. Hollibaugh helped to clarify our concepts. Comments by an unknown reviewer led to definite improvement of a first draft.

AMON, R.M.W. and Benner, R, 1996. Bacterial utilization of diflerent sise classes of dissolved organic matter, Limnol. Oreanogr, 41 , pp. 41-51.

AMADOR, J.A., MIINE. P.J., MOORE, C.A. and ZIKA, R.G., 1990. Extraction of chromophoric humic substances from seawater, Mar. Chem, 99/1, pp. 118.

BE.NER, R., PAKLLSKI, J.D., MCCARTIIY, M., IIEDGES, J.I. and HATCHFR, P.G., 1992. Bulk chemical characteristics of dissolved organic matter in the ocean, Sience, 255. pp. 1561-1564.
BENNER, R., OPSAIII, S., CIIIN-L,EO, G., RICIIEY, J.F., and FORSBERG, B.R. 1995. Baclerial carbon metabolism in the Amazon River system, Iimmol. Ocpanogr, 40, pp. 12621970

BIOLGI, N.Y. ZAFIRIOL, O.C. and BONILLA, J., 1993. Optical absorption spectra of waters from the Orinoco River outflow: Terrestrial input of colored organic matter to the Caribbean, J. Geophys. Res, 98/C.2, pp. $2971-2278$.

BRICALI), A., MOREL, A. and PRIF.UR, I., 1981. Absotption by dissolved organic matter of the sea (ycllow sub-
REFERENCES 
stance) in the UV and visible domains, Limnol. Oceanogr 26. pp. $43-53$.

BROPHY, J.E. and CARISON, 1).]., 1989. Production of biologically refractory dissolved organic carbon by natural seawater microbial populations, Deep-Sea Res., 36 . pp. $197-507$.

CARDFR, KI, STEWARD, R.G., HARVEY, G.R. and ORTNER, P.B., 1989. Marinc humic and fulvic acids: Their cffects on remote sensing of ocean chlorophyll, limnol. Oceanogr, 34, pp. 68-81.

CaRI.SON, C.A. and DLCKL.OW, II.W., 1995. Dissolved organic carbon in the upper ocean of the central cquatorial Pacific Occan, Deet-Sea Res., 12, pp. 639-656.

CHFN, R.F. and BADA, J.I., 1999. The fluoreseence of dissolved organic matter in seawater, Mar Chem, 37, pp. 191g2) 1 .

COBLE, P.G., GREEX, S.A., BIOLGH, N.V. and GAGOSMN, R.B., 1990. Characterization of dissolved organic matter in the Black Sea by fluorescence spectroscopy, Nalure, 348, pp. 132-435.

COLI.INS, KJ. and WLLLIAMS, P.J., LE, B., 1977. An automated photochemical method for the determination of dissolved organic carbon in sca and estuarinc waters, $M a r$. Chem. 5, pp. 123-141.

DH. BAAR, H.J.W., BKLSSAIRI), C., HEGHMAN, J., SCHJF, J. and STOLL. M.H.C., 1993. Sea-trials of three different methods for measuring non-volatile dissolved organic carbon in scawater during the JGOFS North Allantic pilot study, Mar. Chem., 11, pp. 145-152.

DE I LMN, II. and DE BOER, T., 1987. Applicability of light absorbance and fuorescence as measures of concentration and molecular size of dissolved organic carbon in humic Iake Tjeukcmeer, Water Res, 21, pp. 731734.

DE IMAN, I., WERIEMARK, G. and DE BOER, T., 1983. Effect of $\mathrm{pH}$ on molecular reight and size of fulvic acids in drainage water from peaty grassland in NW Netherlands, Plane Soil, 75, pp. 63-73.

DE. HAN, H., JONES, R.I. and SAIONEN, K., 1987. Docs ionic strength alfect the configuration of aquatic humic substances, as indicated by gel filuation ? Freshualer Biol., 17, pp. $453-459$.

DE HAAN, H., HOOGVELD, H.I., DE BOER, T., VOERMAN, J., MOFD, J.R., KRAMER, IIA. and SCHROJEN BOER, J., 1988. Manipulation of chemistry and phytoplankion by hydrological intervention: a whole lake experiment in the northern Netherlands, Freshwater Biol., 20, pp. 395-406.

DELESAI I.E, B. and SOLRNIA, A., 1992. Residence time of water and plytoplankton biomass in coral reel lagoons, Cont. Shell Res., 12, pp. 939-949.

FL'RNAS, M.I., MITCHEI.I, A.W., GILMARTIN, M. and REVEL ANTF, N., 1990. Phytoplankton biomass and primary production in semienclosed reef lagooms of the central Great Barrier Recl, Australia, Coral Reess, 9, pp. 110 .
GLOO L,-D COLFUAN C.1, Ir and SANTSCII, P.II 1994. The distribution of colloidal and dissolved organic carbon in the Gull of Mexico, Mar: Chem., 45, pp. 105-119.

1 IOBBIE, J.E., 1992. Microbial control of dissolved organic carbon in lakes: rescarch for the fu1ure, Hydrobiologia, 299 , pp. $169-180$.

I.E.E, C. and IENRICHS, S.M., 1993. How the nature of dissolved organic matter might affece the analysis of dissolved organic carbon. Mar. (hem., 41, pp. 105-120.

MARTIN, J.H. and FITZWATFR, S.E., 1992. Dissolved organic carbon in the Allantic, Southern and Parific oceans, Nature, 356, pp. 639-700.

MOORE, T.R., 1987. An assessment of a simple: spectropho-tometric method for the detemination of dissolved organic carbon in freshwaters, K.Z.J. Mar. Fresh water Res., 21, pp. 585-589.

MORAN, M.A., POMEROY, I.R., SIHEPPARD, E.S., ATKIASON L.P. and HODSON, R.E., 1991. Distribution of terrestrially derived dissolved organic matter on the southcastern U.S. continentat shelf, Limnol Ocearagr, 36 pp. $1131-1149$.

PACES. I., TORRFETON, J.P. and ANDRFFOLET, S., 1997. Dissolved organic mater in coral-reel lagoons, from in vitro LV absorption. Preliminary results, $8 \mathrm{~h} \mathrm{Im}$. Coral Ref Symp. (Panama), in press.

RICKER, W.E., 1973. Linca regressions in fishery rescarch, J. Fish. Res. Bd. Can, 30, pp. 109-434

SENESI, N., MIANO, T.M., PRONEN/ANO, M.R. and BRU INETTI, G., 1989. Spectroscopic and compositional comparative characterization of 1.ll.S.s. reference and standard fulvic and humic acids of various origin, Srt. toiat Environ., 81, pp. 143-156.

SHICK. JM DUNLAP, W.C. CHLLKER, B.E., BANASZAK, A.T. and ROSFN/WFIG, T.K, 1992. Survey of ultraviolet radiation-absorbing mycospoline-like amino acids in organs of coral reef holothumoids, Mar. Erol. Proge. Ser., 90, pp. $139-148$.

STEWART, A.J. and WET\%EI., R.G., 1980. Fluorescence: absorbance ratios a molecular-weight tracer of dissolved organic nalter, limnol. Ocennogy., 25, pp. 559-564.

STFWART, A.J. and WET'FEI, R.G.. 1981. Asmemical reldtionships between absorbance, fluorescence and dissolved organic carbon, Limnol. Oceanogy, 26, pp. 590-597.

SLMMERS, R.S., CORNEL, P.K. and RORERTS, P.Y. 1987. Molecular sise distribution and spectroscopic characteriration of humic substances. Sci. Total Environm, 62, pp. $27-37$.

TRANVIK, I .]., 1990. Bacterioplankion growth on fractions of dissolved organic carbon of different molecular weight lown humic and clar watcrs, Appl. Entironm. Microbiol, 56, pp. 1679-1677.

VOIACEK, A., IIOGE, FE, SWIFT, R.N., YUNGEL, J.K., PFIT/ER, F..T. and BIOLGH, N.V., 1995. The use of in situ and aiborne fluorescence measurements to determine $\mathrm{LV}$ absorption coefficients and 1$) \mathrm{OC}$ concentrations in surfare waters, Limnol. Oreanogr, 40, pp. 411-41.5. 